\title{
DEL MATRIMONIO CANÓNICO COMO MODELO AL MATRIMONIO CIVIL DECONSTRUIDO: LA EVOLUCIÓN DE LA LEGISLACIÓN ESPAÑOLA*
}

\author{
JaVIer Ferrer Ortiz
}

\section{INTRODUCCIÓN}

Uno de los puntos de reflexión más sugerentes y lúcidos que se viene ofreciendo en Europa en los últimos años para contribuir a la solución de algunos problemas, suscitados básicamente por el laicismo y el multiculturalismo, es la invitación a profundizar en las raíces culturales de Occidente. Para ello suele invocarse una imagen de gran simbolismo y plasticidad, afirmando que la civilización occidental está edificada sobre tres colinas: la Acrópolis de Atenas, el Capitolio de Roma y el Gólgota de Jerusalén ${ }^{1}$. Con esto se quiere decir que pensamos con categorías mentales griegas, los esquemas técnico-jurídicos romanos nos son consustanciales, y la ética que informa el derecho, el pensamiento y la moral es de base judeo-cristiana ${ }^{2}$.

\footnotetext{
* Este texto tiene su origen en la conferencia pronunciada en las Jornadas Internacionales de Derecho en homenaje a Álvaro d'Ors (1915-2004) que, con el título Ciencia Jurídica y Humanismo, se celebraron en la Facultad de Derecho de la Universidad de Piura los días 27 y 28 de agosto de 2010. Colaboración recibida el 11 de julio y aprobada el 20 de septiembre de 2011.

** Catedrático de Derecho canónico y Derecho eclesiástico del Estado, Facultad de Derecho, Universidad de Zaragoza (España). Correo electrónico: jferrer@unizar.es.

${ }^{1}$ La autoría de esta figura de las tres colinas se atribuye a Teodoro Heuss, primer Presidente de la República Federal Alemana (1949-1959), que la utilizó en un discurso que pronunció en Heilbronn (Baden-Wutemberg), el 16 de septiembre de 1950 (cfr. Ledesma Uribe, José de Jesús, "Universalismo y cristianismo en la concepción justiniana del Imperio", Jurídica. Anuario del Departamento de Derecho de la Universidad Iberoamericana, 18, 1986, p. 76).

${ }^{2}$ Esta explicación la encontramos con diversas variantes en distintos escritos, unos de carácter científico, otros de carácter ensayístico, de Navarro Valls, uno de los autores que, a mi juicio, ha contribuido con mayor acierto y rigor a iluminar los debates suscitados en diversos escenarios a propósito de asuntos como el valor formativo y cultural del estudio del Derecho canónico en la Universidad, la mención del patrimonio espiritual y moral en el preámbulo de la Carta de los derechos fundamentales de la Unión Europea, etc. (cfr. NAVARRO-VAlLS, Rafael, "La enseñanza universitaria del Derecho Canónico en la jurisprudencia española", Anuario de Derecho Eclesiástico del Estado, 1985, p. 74; Navarro-Valls, Rafael, "Basidella cultura giuridica europea", Anuario de Derecho Eclesiástico del Estado, 2002, p. 25 [versión española en Anales de la Real Academia de Jurisprudencia y Legislación, 2002, p. 377]; NAVARRO-VAlLS, Rafael, Del poder y de la gloria, Ediciones Encuentro, Madrid, 2004, p. 268; e NaVARRO-Valls, Rafael, Entre la Casa Blanca y el Vaticano, Ediciones Internacionales Universitarias, Madrid, 2009, p. 315).
} 
A los efectos que ahora interesa destacar, se comprende la importancia que tiene el estudio del Derecho romano en la formación del jurista. En palabras de Álvaro d'Ors: "La virtud ejemplar (...) por la que debe seguir siendo estudiado en la actualidad, consiste en haber sido fundamentalmente un derecho científico, es decir, jurisprudencial, y no un orden impuesto por el legislador" ${ }^{\prime \prime}$. Se entiende así, siguiendo al maestro, que "este estudio romanístico constituye para el jurista moderno la primera disciplina de su formación mental, es decir, sus "humanidades". En él se ha formado la tradición de la ciencia jurídica europea, difundida más allá de los límites continentales. El Derecho Privado Romano es así el derecho "civil", es decir, el "civilizado" y común a los pueblos cultos, hasta la época de las modernas codificaciones. Se difundió por la influencia de la enseñanza universitaria que empieza en Bolonia, en el s. XII, con el gramático Irnerio. Alcanza un gran prestigio con Bártolo, en el s. XIV, quien puede ser considerado como el más influyente jurista de todos los siglos; él es el máximo artífice del "Derecho Romano Común", que, asociado al "Derecho Canónico" para formar el utrumqueius ("ambos derechos"), constituye el fundamento de la cultura jurídica europea" ${ }^{\prime 4}$.

Entre las manifestaciones de esta herencia jurídica se incluye la circunstancia de que en Occidente la mayor parte de las instituciones del Derecho privado y, señaladamente, del Derecho civil, hunden sus raíces en el Derecho romano; de ahí que pueda afirmarse categóricamente que constituye su Derecho clásico. No obstante este principio general tiene una excepción de notable importancia, porque el Derecho clásico del matrimonio es el Derecho canónico y no el Derecho romano; y de hecho, el matrimonio civil contemporáneo sólo se entiende como el resultado de un proceso de secularización y desvirtuación de la construcción técnica del matrimonio elaborada por los canonistas medievales ${ }^{5}$.

Este reconocimiento del origen canónico de la regulación jurídica del matrimonio en Occidente es un hecho pacíficamente admitido entre los juristas en general, no sólo entre los canonistas. Resulta elocuente la explicación que ofrece Álvaro d'Ors ya en la primera edición de sus Elementos de Derecho privado romano: "La institución matrimonial de los pueblos civilizados ha sido formada en la disciplina del Derecho Canónico y el Derecho Romano nada tiene

\footnotetext{
${ }^{3}$ D'Ors, Álvaro, Derecho Privado Romano,10a Edición Revisada, Eunsa, Pamplona, 2004, p. 31.

${ }^{4}$ Ibidem, pp. 35-36. Para valorar la importancia de los autores citados me remito a CUENA, Francisco, "Irnerio", en Domingo, Rafael (Ed.), Juristas universales, 1, Juristas antiguos, Marcial Pons, Madrid, 2004, pp. 309314; y García Garrido,Manuel Jesús,"Bártolo de Sassoferrato", en ibidem, pp. 524-530. Para completar la referencia se hace necesario mencionar a Graciano, considerado el padre de la ciencia canónica, y acudir a la semblanza que de él ofrece De LEón, Enrique,"Graciano", en ibidem, pp. 314-319.

${ }^{5}$ Cfr., por todos, González del Valle, José María,Derecho canónico matrimonial según el Código de 1983, Eunsa, Pamplona, 1983, p. 13; y Lombardía, Pedro, Lecciones de Derecho Canónico, Tecnos, Madrid, 1984, p. 52.
} 
que enseñar al jurista moderno en este terreno. La mentalidad pagana no llegó a penetrar en la verdadera esencia del matrimonio; sólo el mensaje cristiano del Amor Divino dio la luz justa sobre la naturaleza del amor matrimonial y su función en la economía providencial de la vida humana"6. La idea se conserva sustancialmente inalterada hasta nuestros días en las sucesivas ediciones de su Derecho privado romano, aunque con una formulación ligeramente retocada que le otorga mayor fuerza: "La mentalidad pagana, a la que resultaba inaccesible la verdadera esencia del Amor, no pudo alcanzar una concepción válida del matrimonio, y para el jurista moderno el derecho 'clásico', respecto a esta institución, es el Derecho Canónico"7.

Esta misma afirmación la encontramos recogida y desarrollada por Xavier d'Ors, que añade: "Y si a veces los juristas medievales -y de modo especial los canonistas- invocan ideas o principios procedentes del sistema matrimonial de Roma, ello se debe, no a que consideren su nuevo derecho matrimonial como continuación del romano, sino más bien al intento de dar legitimidad, por vía de tradición, a algunos aspectos de ese nuevo derecho matrimonial. Así, pues, no existe una auténtica recepción del sistema matrimonial romano, sino sólo una simple invocación de algunos principios del mismo -incluso a veces no comprendidos, cuando no tendenciosamente interpretados- que podían servir de apoyo al nuevo matrimonio canónico" ${ }^{\prime \prime}$.

\section{DereCho Romano y MATRIMONIO CRISTIANO}

En los primeros tiempos de su existencia, la Iglesia carece de una regulación propia del matrimonio, aceptando la que le ofrece la sociedad de entonces, en cuanto respeta el Derecho natural y el Derecho divino positivo. De esta forma, desde sus comienzos, el cristianismo se esfuerza por devolver al matrimonio a su estado original, reafirmando sobre todo la indisolubilidad frente al repudio judío, permitido por Moisés, y frente al divorcio, ampliamente admitido en el mundo antiguo. A este propósito, conviene recordar que el matrimonio romano era una situación de convivencia de dos personas de distinto sexo, socialmente honorable, fundada sobre la affectio maritalis o intención constante de vivir como marido y mujer. El consensus que sustentaba esta última no era propiamente un acto de voluntad inicial proyectado en el tiempo, sino un estado de la voluntad cuyo cese determinaba la desaparición del matrimonio. Esto podía suceder en cualquier momento por la voluntad de uno de los cónyuges y, de

${ }^{6}$ D'Ors, Álvaro, Elementos de Derecho Privado Romano, Studium Generale, Pamplona, 1960, p. 245.

${ }^{7}$ D'Ors, Derecho Privado, cit. nota n. 3, p. 307.

${ }^{8}$ D'Ors, Xavier, "Principios y criterios fundamentales de estructuración del sistema matrimonial en el Derecho romano", en VV.AA., Libertades fundamentales y sistema matrimonial. V. Congreso Internacional de Derecho eclesiástico del Estado. Ponencias 1, Pamplona, 1990, p. 1. 
ordinario, era formalmente comunicada al otro (dicho acto recibía el nombre de repudium, mientras que se denominaba divortium al hecho mismo del cese del matrimonio por la separación de los cónyuges). También se extinguía por la muerte, o por la pérdida de la libertad o de la ciudadanía de uno de los cónyuges. En definitiva, el matrimonio romano era un situación de hecho (res facti) con consecuencias jurídicas ${ }^{9}$.

"En los siglos siguientes -escribió Orlandis-, en especial desde que la conversión del Imperio romano al Cristianismo abrió a la doctrina evangélica las puertas de la legislación civil, la línea de avance social y jurídico tuvo una dirección bien marcada: la afirmación del matrimonio único e indisoluble, la gradual limitación del divorcio, la restricción del concubinato de los casados y en cambio la paulatina equiparación al matrimonio del concubinato estable de personas libres. La unidad e indisolubilidad matrimonial de la doctrina evangélica se consideró entonces -y se siguió considerando en épocas posteriorescomo un signo de civilización y la meta ideal hacia la que habría de tender la dinámica del progreso humano"10.

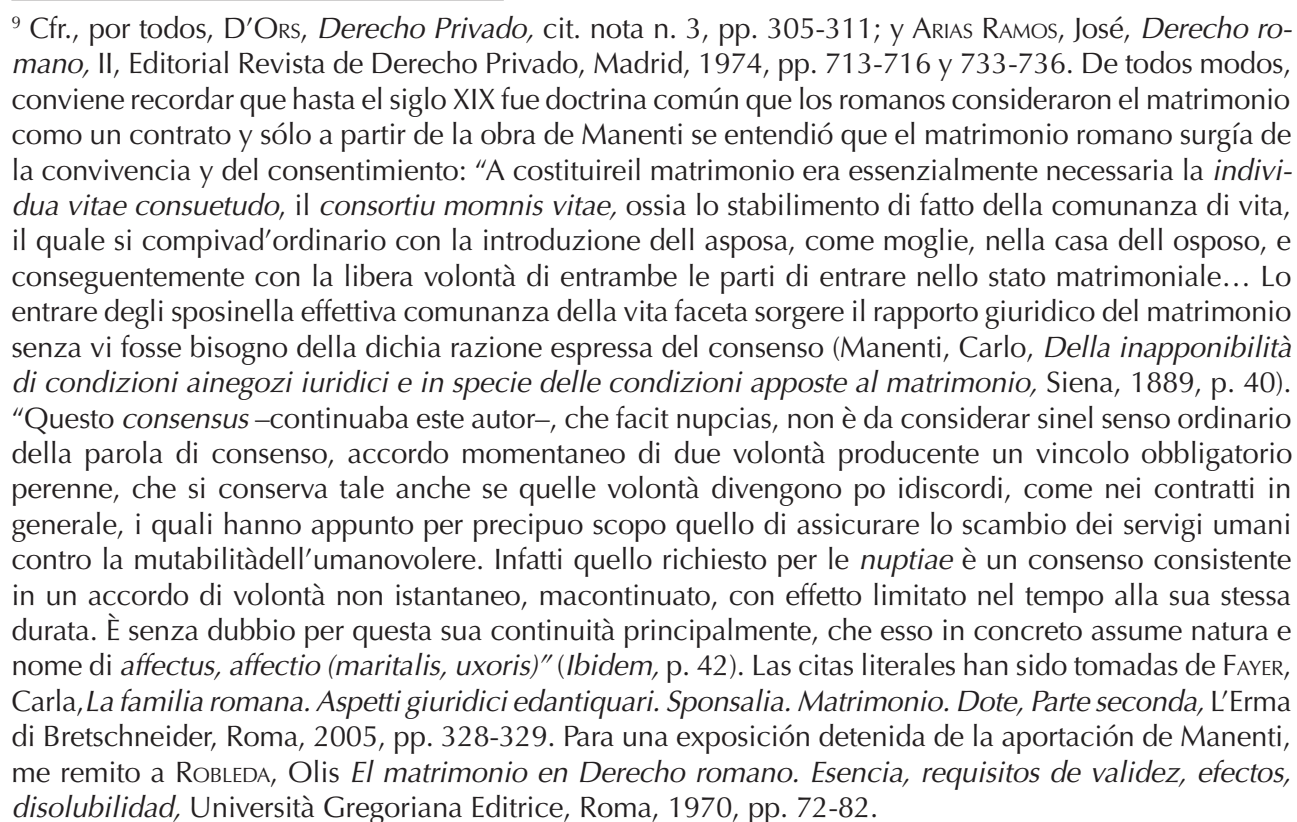

${ }^{10}$ OrLandis, José, La vida cristiana en el siglo XXI, Rialp, Madrid, 2001, pp. 70-71. No obstante, ya en tiempos de Constantino se observan algunos cambios que, en buen parte, encuentran en el cristianismo su fuente de inspiración (cfr. Domingo, Rafael, La legislación matrimonial de Constantino, Servicio de Publicaciones de la Universidad de Navarra, Pamplona, 1989, pp. 91-93). Sin embargo, el influjo civilizador que sobre el matrimonio tuvo el cristianismo primero y más tarde el Derecho canónico ha sido negado por Schulz, para quien "el Derecho clásico del matrimonio es, sin duda alguna el logro del genio jurídico de Roma. Ya en los primeros tiempos de la historia de la civilización, apareció un 
El matrimonio canónico va asimilando y cristianizando diversos elementos que toma del Derecho judío, del Derecho romano y del Derecho germánico, hasta alcanzar una construcción técnica de altísimo nivel en la Edad Media. Es entonces cuando se produce el asentamiento del principio consensual, con todas sus consecuencias, al que más tarde se añade la forma de celebración como requisito de validez, en el Concilio de Trento (Decreto Tametsi 1563), aunque todavía debieron transcurrir varios siglos hasta que la forma ad validitatem se universalizara, mediante el Decreto Ne temere (1907).

En definitiva, puede afirmarse que la recepción del Derecho romano en Europa, tan decisiva en las demás ramas del Derecho privado, fue muy limitada en el ámbito del Derecho matrimonial, si se exceptúa la incorporación de algunos aforismos romanos, que aportaban mayor respetabilidad y vigor formal al Derecho canónico, aunque fueran libremente interpretados por éste. Así, por ejemplo, fueron acogidas dos célebres definiciones del matrimonio, una atribuida a Ulpiano y la otra a Modestino, pero dándoles un alcance y un significado algo distintos ${ }^{11}$; y lo mismo sucede, de forma más acusada, con el con el brocardo romano nuptias non concubitus, sed consensus facit ${ }^{12}$. Para los canonistas no se trata de un consensus continuado, sino de un consensus pacticio, lo que constituye una de sus grandes aportaciones al Derecho matrimonial. Del intercambio de voluntades entre el varón y la mujer, en un lugar y tiempo determinados, surge un vínculo jurídico perpetuo y exclusivo, que no necesita renovarse cada día. Ese acto de entrega y aceptación mutua de los contrayentes en cuanto cónyuges será la causa eficiente del matrimonio, lo que les convierte en marido y mujer (sociedad conyugal).

Derecho matrimonial humano, esto es, basado en la idea humana del matrimonio concebido como unión libre y disoluble en que viven ambos cónyuges en pie de igualdad" (ScHulz, Fritz, Derecho Romano Clásico, Casa Bosch, Barcelona, 1960, p. 99). Se comprende que su posición, decididamente favorable al divorcio, hace de éste la piedra angular sobre la que descansa la construcción jurídica de Roma y que considere inhumana su abrogación por parte del Derecho canónico (cfr. ibidem, p. 100).

${ }^{11}$ La definición que se atribuye a Ulpiano, contenida en las Instituciones de Justiniano $(I, 1,9,1)$ dice así: "Nupcias o matrimonio es la unión del varón y de la mujer, que contiene la comunidad indivisible de vida"; y la de Modestino, contenida en el Digesto (D. 23, 3, 1): "Las nupcias son la unión del varón y de la mujer, consorcio de toda la vida, comunión en el derecho divino y en el humano". Como explica Fornés, la definición de Modestino nunca aparece propuesta en el Derecho canónico clásico de modo autónomo, sino unida o relacionada de alguna manera con la de Ulpiano, que fue la más utilizada, aunque retocada para adaptar la concepción romana del matrimonio a la visión cristiana. En concreto, sirvió de modelo a la definición de Pedro Lombardo († 1160), seguida luego por teólogos y canonistas: "Las nupcias o el matrimonio son la unión marital de varón y mujer, entre personas legítimas, que retiene una comunidad indivisible de vida" (cfr. ForNés, Juan, Derecho matrimonial canónico, $5^{a}$ Edición, Tecnos, Madrid, 2008, pp. 16-17). Para una explicación del sentido de las definiciones romanas en sí mismas consideradas, me remito a ROBLEDA, El matrimonio, cit. nota n. 9, pp. 59-71.

${ }^{12}$ Cfr. Hervada, Javier-Lombardía, Pedro, El Derecho del Pueblo de Dios. Hacia un sistema de Derecho Canónico, III, Derecho Matrimonial (1), Eunsa, Pamplona, 1973, pp. 279-281. 


\section{MATRIMONIO CIVIL Y SISTEMAS MATRIMONIALES}

Durante varios siglos, el matrimonio canónico fue prácticamente el único matrimonio vigente en una Europa cristiana, sometido en su regulación sustantiva y procesal a la autoridad eclesiástica, sin perjuicio de las disposiciones dictadas por la autoridad civil para completar a las anteriores. Sin embargo, a partir del siglo XVI, con la Reforma y la consiguiente división de Europa en Estados católicos y protestantes, cambia la situación. En efecto, los protestantes consideran el matrimonio como una institución natural, de origen divino y carácter civil (niegan la sacramentalidad del matrimonio entre bautizados), cuya competencia legislativa y judicial corresponde a la autoridad temporal, dejando a salvo lo que pueda disponer la autoridad religiosa respecto al rito de celebración. Los Estados donde se imponen los reformadores se apresuran a disciplinar el matrimonio de sus súbditos, aunque al principio se trata de un matrimonio religioso, propio de la confesión dominante -cuius regio eiusreligio-, regulado por normas civiles. De esta forma, la ruptura de la unidad religiosa de Occidente, supuso la aparición de un mosaico de matrimonios y el desconocimiento del canónico por parte de determinados Estados.

La existencia de esta pluralidad de ordenamientos jurídicos civiles, cada uno de ellos con su propia legislación sobre el matrimonio religioso, va a sentar las bases para la aparición del matrimonio civil. La figura surge por vez primera en Holanda, en 1580, en aplicación del principio de tolerancia, al permitir que los disidentes de la religión oficial -calvinista-, puedan celebrar matrimonio con efectos civiles ante el magistrado civil. $Y$ aunque en su origen se trata de un matrimonio subsidiario del religioso termina por imponerse como única clase de matrimonio, que puede celebrarse tanto en forma civil como en forma religiosa. Más tarde, en 1563, se produce una efímera introducción del matrimonio civil como obligatorio en Inglaterra, Escocia e Irlanda. El sistema no se generaliza hasta el siglo XIX, cuando un buen número de Estados hacen suya la concepción del matrimonio como mero contrato civil, disoluble mediante divorcio, adoptada por la Constitución francesa de 1791 y el Código napoleónico de 1804. En esta época, el matrimonio civil ya no es patrimonio exclusivo de los países de raíces protestantes, sino que también se introduce en países de tradición católica, como resultado de la difusión de las tesis regalistas y laicistas que, por diversos caminos, conducen al predominio de la jurisdicción civil sobre la eclesiástica en materia de matrimonio y a su secularización ${ }^{13}$. Naturalmente, esta situación es compatible con la firma de concordatos con la Iglesia Católica, en los que el Estado reconoce efectos civiles al matrimonio canónico y a las sentencias y

${ }^{13}$ Cfr. De Fuenmayor, Amadeo, "El matrimonio y el Concordato español”, lus Canonicum 1963, pp. 274-278. 
resoluciones eclesiásticas, aunque cada vez los somete a mayores controles, imponiéndoles la observancia de más normas civiles de las que podrían considerarse razonables o estrictamente necesarias.

Una vez trazado este panorama, ya se comprende que si de una parte la Iglesia Católica (con menor intensidad las demás confesiones) y de otra parte los Estados afirman su competencia sobre el matrimonio, sea en términos excluyentes o cumulativos, se hace necesario determinar el sistema de relación entre los distintos matrimonios que, de hecho, pueden contraer las personas dentro de un mismo territorio. Surgirá así el concepto de sistema matrimonial, que girará principalmente en torno al binomio matrimonio civil-matrimonio religioso, exponente de una cuestión más de fondo como es la relación entre el poder temporal y el poder espiritual, y la competencia de cada uno de ellos sobre el matrimonio ${ }^{14}$.

Como a partir de este momento la historia de cada país se diversifica notablemente, centraré mi exposición en España, para mostrar la evolución experimentada por el matrimonio civil desde su aparición, tomando como modelo la construcción técnico-jurídica del matrimonio canónico, hasta llegar al momento actual. Pretendo así evitar una exposición enciclopédica, que difícilmente podría conjurar el peligro de incurrir en generalizaciones; y aunque el espacio de que dispongo es ciertamente reducido, trataré de ofrecer una panorámica sustancialmente completa de los aspectos sustantivos del matrimonio civil en España.

\section{MONOPOlio del matrimONiO CANÓNICO En España}

Hasta finales del siglo XV y comienzos del XVI se da una pluralidad de regímenes matrimoniales en la Península Ibérica, como consecuencia de la convivencia de judíos, cristianos y musulmanes. El cambiante mapa político de la Reconquista, con avances y retrocesos constantes, donde musulmanes y

\footnotetext{
14 "A partir de estas consideraciones podemos denominar régimen matrimonial al conjunto de normas relativas a los requisitos de capacidad, consentimiento y forma, así como a la separación, nulidad y disolución del matrimonio. La expresión comprende los aspectos sustantivos del matrimonio, sea éste religioso o civil, a los que también cabe referirse con la expresión derecho matrimonial, seguida del adjetivo que corresponda: canónico, civil, judío, islámico, etc. En cambio, por sistema matrimonial entendemos, en sentido amplio, el criterio que cada ordenamiento adopta para reconocer como matrimonio, con sus efectos jurídicos, los modos de comunidad de vida establecidos entre hombre y mujer; o, también, la fórmula jurídica empleada por el legislador para delimitar los términos de la obligatoriedad y eficacia de los diversos regímenes matrimoniales -civiles, religiosos, o civiles y religiosos al mismo tiempo- que concurren en el seno de un ordenamiento. Esta noción es técnicamente omnicomprensiva por cuanto no limita su problemática a las relaciones entre matrimonio civil y matrimonio religioso, sino que incluye todos los posibles regímenes matrimoniales vigentes en un ordenamiento" (FERRER ORTIZ, Javier, Matrimonio religioso y ordenamiento estatal, Comunicación presentada en el XVI Congreso Internacional de Derecho Familiar, celebrado en la Universidad Autónoma de Santo Domingo (República Dominicana), los días 18-22 de octubre de 2010, pp. 1-2 [pro scriptis]. Se corresponde con el texto de la voz "Sistemas matrimoniales", en Instituto Martín de Azpilcueta, Diccionario General de Derecho Canónico [en prensa]).
} 
cristianos pasan fácilmente de dominadores a dominados, impone una diversidad matrimonial fundada en el principio de reciprocidad y en la necesidad práctica de hacer posible la convivencia de personas pertenecientes a distintas religiones y culturas. No estamos propiamente ante un sistema de libertad religiosa, sino de tolerancia, como lo confirman los intentos de la comunidad dominante de imponer su religión a las demás y la prohibición de los matrimonios mixtos. Así pues, como regla general, se reconoce socialmente el matrimonio contraído por los miembros de cada comunidad religiosa según su propia normativa confesional.

Esta diversidad matrimonial va desapareciendo gradualmente, a favor del matrimonio canónico, a medida que se extiende la unificación política y religiosa. La toma de Granada por los Reyes Católicos, en 1492, es el hito que marca el final de la Reconquista y el inicio del proceso de configuración de España como Estado moderno. Ese mismo año se dicta el decreto de expulsión o conversión de los judíos y, a partir de 1502, se suceden diversas órdenes en idéntico sentido respecto a los musulmanes, con lo que tanto éstos como aquéllos se ven en la disyuntiva de convertirse al cristianismo o abandonar el territorio. Así pues, en los albores de la Edad Moderna, nos encontramos con que los judíos y los musulmanes desaparecen oficialmente de España, mientras que los primeros focos del incipiente protestantismo serán reprimidos como consecuencia de la simbiosis, característica de la época, entre religión y política, de manera que el rito matrimonial fijado por Lutero en 1529 no será admitido en el territorio español. Por su parte, el matrimonio canónico adquiere un predominio absoluto, del que es expresión jurídica la Real Cédula de 12 de julio de 1564, en la que Felipe II acepta y recibe los decretos del Concilio de Trento -entre ellos, el Tametsi, sobre la reforma del matrimonio-, estableciendo que en sus Reinos sean guardados, cumplidos y ejecutados. En su virtud, la Corona reconoce la competencia de la Iglesia Católica en todo lo relativo a la disciplina sustantiva y procesal del matrimonio, reservándose tan sólo la facultad de completarla regulando los efectos meramente civiles del matrimonio y estableciendo algunas prohibiciones para contraerlo ${ }^{15}$. Desde entonces, el reconocimiento del matri-

\footnotetext{
${ }^{15}$ No obstante, hubo una interesante excepción en las Indias españolas, donde los matrimonios contraídos por los naturales del lugar según sus propias normas y costumbres fueron reconocidos inicialmente, de acuerdo con la doctrina de la Iglesia católica sobre la validez del matrimonio de infieles, siempre que fuera conforme con el Derecho natural (matrimonio legítimo). En la medida en que la conquista y evangelización fueron graduales y se respetó la libertad de los indios para abrazar o no el cristianismo, estos matrimonios continuaron celebrándose (cfr. De Jorge García ReYes, Juan Antonio, El matrimonio de las minorías religiosas en el Derecho español, Tecnos, Madrid, 1986, pp. 117-127).
} 
monio canónico por parte del ordenamiento estatal ha sido la cuestión clave del sistema matrimonial español ${ }^{16}$.

En el período comprendido entre 1564 y 1870 el único matrimonio presente en nuestro Derecho histórico es el matrimonio canónico, mientras el matrimonio religioso de judíos y musulmanes subsiste en la clandestinidad y el matrimonio civil se extiende por los países en que triunfa la reforma protestante y, más tarde, los ideales de la Revolución francesa, secularizando la institución.

\section{INTRODUCCIÓN DEL MATRIMONIO CIVIL: LA LEY DE 1870}

El panorama cambia radicalmente en España con la Ley de matrimonio civil de 18 de junio de 1870 que, después de varios intentos de hacer del matrimonio una cuestión profana y someterla al Derecho estata ${ }^{17}$, introduce un sistema de matrimonio civil obligatorio. El legislador admite un único tipo de matrimonio, el civil, configurado como una versión laica o secular del canónico, de ahí el paralelismo que conserva con él en materia de capacidad, consentimiento y forma, causas de nulidad y separación, sin olvidar la afirmación inicial de la ley de que "el matrimonio es por su naturaleza perpetuo e indisoluble" (art. 1).

Montero Ríos, autor material del proyecto que terminaría convirtiéndose en ley siendo ya Ministro de Gracia y Justicia, reconocería abiertamente que "la legislación matrimonial de la Iglesia es la más perfecta, la más acabada de todas las conocidas. Lo bueno debe copiarse siempre y donde quiera que se encuentre" ${ }^{\prime 18}$. En consecuencia, decía que tan sólo pretendía convertir la legislación canónica en civil, de tal manera que los ciudadanos se casaran civilmente con las mismas condiciones con que antes se casaban en la Iglesia, y sin perjuicio de que, como disponía la ley, "los contrayentes podrán celebrar el matrimonio religioso antes, después o al tiempo del matrimonio civil" (art. 34).

La discusión parlamentaria se centró en el artículo 2, que establecía la obligatoriedad de la forma civil de celebración -"el matrimonio que no se celebre con arreglo a las disposiciones de esta ley, no producirá efectos civiles con

\footnotetext{
${ }^{16}$ De hecho se ha podido decir que "en ella han confluido con especial intensidad las tensiones políticas y sociológicas acerca de la noción misma de matrimonio; ella ha sido el índice del grado de aceptación o rechazo del hecho religioso por el poder constituido, y al hilo de las diversas soluciones técnicas acogidas para valorarlo, positiva o negativamente, es factible reconstruir no sólo la historia de un concreto instituto jurídico, sino también la historia de las relaciones Iglesia-Estado en España" (Navarro Valls, Rafael, "La posición jurídica del matrimonio canónico en la Ley de 7 de julio de 1981", Revista de Derecho Privado, 1982, p. 667).

${ }^{17}$ El proceso se inició con el Proyecto de Código civil de 1821, al que siguieron los Proyectos de 1836, 1843 y 1851, además de varios proyectos particulares (cfr. CRESPO DE MigueL, Luis, La secularización del matrimonio. Intentos anteriores a la Revolución de 1868, Eunsa, Pamplona, 1992).

${ }^{18}$ Citado por NavarRo VAlls, Rafael, "El modelo matrimonial de la legislación histórica española", Revista de la Facultad de Derecho de la Universidad Complutense de Madrid, 1981, p. 209.
} 
respecto a las personas y los bienes de los cónyuges y de sus descendientes"-, mientras que el resto de sus preceptos quedaron relegados a un segundo plano. Y es que, como afirmó Falcón, así como toda la sabiduría de la ley estaba en su artículo primero [matrimonio perpetuo e indisoluble], todo su error no pasó del artículo segundo[matrimonio civil obligatorio] ${ }^{19}$.

Por todo ello, se ha convertido en un lugar común decir que la Ley de 1870 "tan sólo (...) quiso sustituir el sacerdote por el juez; la Iglesia por el Juzgado, la Biblia por los artículos de la ley, y los Tribunales eclesiásticos por los civiles" ${ }^{\prime 20}$.

De todos modos, un examen detenido de su articulado y de los debates parlamentarios, permite sostener que no estamos ante una simple cuestión de competencia de jurisdicciones -ciertamente fundamental-, sino que detrás vienen muchas otras cuestiones de fondo ${ }^{21}$. Así por ejemplo, si bien es cierto que, como hemos recordado, la ley afirma que "el matrimonio es por su propia naturaleza perpetuo e indisoluble" (art. 1), el preámbulo del proyecto reconoce que "el Ministro no ha de entrar en una exposición puramente especulativa acerca de si esas cualidades son o no esenciales al matrimonio"22, limitándose a declarar la necesidad y conveniencia prácticas de recogerlas en la legislación. En cuanto a la edad para contraer matrimonio, se inspira en la legislación canónica, haciendo coincidir la pubertad con la edad núbil, pero se aparta de ella porque la ley civil la fija con presunción iuris et de iure a los 12 años en la mujer y a los 14 años en el varón, y también porque prevé la convalidación automática del matrimonio de impúberes (art. 4). El impedimento de consanguinidad resulta algo más reducido que el canónico (art. 6). Por lo demás, las normas sobre dispensas (art. 7), diligencias previas (art. 9 y ss.) y forma de celebración (art. 28 y ss.), hechas las oportunas salvedades, mantienen el paralelismo y la semejanza con las correlativas normas canónicas. Lo mismo cabe decir de los

\footnotetext{
${ }^{19}$ Cfr. Carrión Olmos, Salvador, Historia y futuro del matrimonio civil en España, Editorial Revista de Derecho Privado-Editoriales de Derecho Reunidas, Madrid, 1977, p. 200.

${ }^{20}$ Puig PeÑa, Federico, Tratado de Derecho Civil Español, tomo II Derecho de familia, volumen I Teoría general del matrimonio, Editorial Revista de Derecho Privado, Madrid, 1947, p. 61. En parecidos términos se afirmó: "El sacerdote sustituido por el juez, el sillón del magistrado puesto en lugar del altar, el Espíritu Santo destituido, y en su lugar un testimonial humano, semejante al que se pone en uso en cualquier importante contrato; el Estado atando a los consortes, dispensando a los pretendientes, suspendiendo los lazos de la unión marital, éste es el cuadro vivo de aquella ley no reclamada por la nación" (VILARRASA, Eduardo María; Gatell, José Ildefonso, Historia de la Revolución de Septiembre. Sus causas, sus personajes, sus doctrinas y sus resultados, tomo I, Barcelona, 1875, p. 890, citados por Martí Gilabert, Francisco, El matrimonio civil en España. Desde la República hasta Franco, Eunsa, Pamplona, 2000, p. 68).

${ }^{21}$ Cfr. CARrIón, Historia y futuro, cit. nota n. 19, pp. 155-173; y NAVARRO, "El modelo matrimonial”, cit. nota n. 18 , pp. 207-211.

22 "Preámbulo del proyecto", Revista General de Legislación y Jurisprudencia, 1870, p. 257.
} 
impedimentos de crimen, en sus figuras de adulterio y conyugicidio (art. 6, $7 .{ }^{\circ}$ y $8^{\circ}{ }^{\circ}$, de orden sagrado y de voto (art. 5, 2..$^{\circ}$. La Ley de 1870 también civiliza el matrimonio putativo (art. 94) y el matrimonio por poder (arts. 35 y 36); así como algunas causas canónicas de nulidad como el error en la persona, la coacción y el miedo grave (art. 92, 4..$^{\circ}$ ), y el impedimento del rapto (art. 92. 5. ${ }^{\circ}$ ), aunque introduce la convalidación automática por el transcurso de seis meses de cohabitación, a contar desde el desvanecimiento del error o la recuperación de la libertad, sin reclamar la nulidad (art. 92, in fine). En cuanto a las causas de separación (entonces llamadas impropiamente de divorcio, siendo éste no vincular) se observa también la inspiración canónica, aunque con alguna novedad, como la diferencia entre el adulterio del varón y el de la mujer: el de ésta era causa de separación en todo caso, salvo que hubiera sido remitido expresa o tácitamente por el marido (art. 85, ${ }^{\circ}{ }^{\circ}$ ), mientras que el del varón sólo si era "con escándalo público o con el abandono completo de la mujer, o cuando el adúltero tuviese a su cómplice en la casa conyugal, con tal que no hubiera también sido remitido expresa o tácitamente por la mujer" (art. 85, 2. ${ }^{\circ}$ ).

A pesar de lo dicho, la legislación civil se aparta claramente de la canónica en algunos extremos. Así ocurre cuando rechaza en absoluto la promesa de matrimonio (art. 3); o cuando exige que la impotencia física, absoluta o relativa, antecedente, perpetua, incurable y patente, sea para la procreación (art. 4, 3. ${ }^{\circ}$ ), especificación esta última que parece ignorar la distinción básica entre impotencia y esterilidad, presente en la regulación canónica. También es distinto el régimen relativo a la presunción de muerte (art. 90), y el preámbulo de la Ley rechaza expresamente la civilización de la sanación en la raíz porque "es por su naturaleza propia del orden espiritual y no puede acomodarse a la índole y condiciones del poder del Estado"23. Quizás por estas mismas razones la Ley de 1870 no civiliza el matrimonio canónico secreto, lo que no deja de ser llamativo si se considera que fue precisamente la conveniencia de una reglamentación paralela a la canónica la que llevó unos años más tarde, mediante Real Decreto de 19 de marzo de 1906, a introducir el matrimonio secreto civil en el ordenamiento español ${ }^{24}$. Por último, conviene señalar que la Ley no dedica precepto alguno a la simulación del matrimonio y tampoco contiene expresamente el principio de que no hay matrimonio sin consentimiento matrimonial, aunque varias de las causas de nulidad están referidas a defectos o vicios del consentimiento. Por lo demás, la exigencia de que a la pregunta del juez: ¿Queréis por esposa (o esposo)...? , contesten los contrayentes por orden: Sí quiero (art. 38), no permite extraer ninguna conclusión al respecto.

23 "Preámbulo del proyecto", cit. nota n. 22, p. 283.

${ }^{24}$ Cfr. García Cantero, Gabriel, El vínculo del matrimonio civil en el Derecho español, Consejo Superior de Investigaciones Científicas, Roma-Madrid, 1959, pp. 211-213. 
No es este el momento de recordar con detalle que el proyecto de Ley de matrimonio civil encontró una gran oposición dentro y fuera de las Cortes y que fue aprobado por sorpresa, merced a un ardid de Ruiz Zorrilla, Presidente de la Cámara, en una extraña votación que se saldó con veintiocho votos favor y dos en contra ${ }^{25}$. Bastará añadir que la Ley resultó a todas luces impopular, que el matrimonio civil resultaba una parodia del matrimonio canónico y que la ciudadanía mostró mayoritariamente su rechazo y continuó contrayendo matrimonio religioso, por más que careciera de efectos civiles. Esta actitud motivó la derogación parcial de la Ley, mediante Real Decreto de 9 de febrero de 1875, que restableció el matrimonio canónico y mantuvo el matrimonio civil para quienes no profesaran la religión católica. De esta forma, quedó instaurado un sistema de matrimonio civil subsidiario del matrimonio canónico.

\section{Dos Clases o formas de matrimonio: el Código CiVIL de 1889}

Este sistema fue incorporado a la Ley de Bases de $1888^{26}$ y de ahí pasó al Código civil de 1889 (C.c.), que en su artículo 42 dispuso: "La ley reconoce dos formas de matrimonio: el canónico, que deben contraer todos los que profesan la Religión católica, y el civil, que se celebrará del modo que determine este Código". En consecuencia, abstracción hecha del paréntesis de la Segunda República -en el que el se introdujo un sistema de matrimonio civil obligatorio y el divorcio, y se derogó el artículo 42 C.c. ${ }^{27}$-, la interpretación del término profesar será la cuestión clave durante casi un siglo: en las etapas en que se

\footnotetext{
${ }^{25}$ Cfr. Martí Gilabert, Francisco, El matrimonio civil en España, cit., pp. 116-125. La denominada travesura de Ruiz Zorrilla tuvo lugar el 24 de mayo de 1870, cuando éste interrumpió el discurso de un diputado sobre un proyecto de ley de organización provincial y municipal, con la excusa de proceder a la aprobación de varios proyectos de ley. En aquel momento eran muy pocos los diputados presentes en la sala y el secretario leyó en voz tan tenue las disposiciones objeto de aprobación, que la mayoría de los presentes no advirtió qué estaban aprobando (cfr. De FuenMAYOR, Amadeo,"El matrimonio como contrato civil", Revista General de Legislación y Jurisprudencia, 1976, pp. 97-98).

${ }^{26}$ En concreto, a la Base 3. ${ }^{a}$, negociada oficiosamente con la Santa Sede: "Se establecerán en el Código dos formas de matrimonio: el canónico, que deberán contraer todos los que profesen la religión católica, y el civil, que se celebrará del modo que determine el mismo Código, en armonía con lo prescrito en la Constitución del Estado. El matrimonio canónico producirá todos los efectos civiles respecto de las personas y bienes de los cónyuges y sus descendientes, cuando se celebre en conformidad con las disposiciones de la Iglesia católica, admitidas en el Reino por la ley 13 , título $1^{\circ}$, libro $1 .{ }^{\circ}$ de la Novísima Recopilación. Al acto de su celebración asistirá el Juez municipal u otro funcionario del Estado con el solo fin de verificar la inmediata inscripción del matrimonio en el Registro civil".

${ }^{27}$ La Constitución de 1931 determinó en su artículo 43.1 que "el matrimonio (...) podrá disolverse por mutuo disenso o a petición de cualquiera de los cónyuges, con alegación en este caso de justa causa". Más tarde, se dictó la Ley de divorcio, de 2 de marzo de 1932, a la que siguió la Ley de matrimonio civil, de 28 de junio de 1932. El artículo 1 de esta última dispuso que "a partir de la vigencia de la presente Ley sólo se reconoce una forma de matrimonio, el civil, que deberá contraerse con arreglo a lo dispuesto en las Secciones $1 .{ }^{a}$ y $2 .^{\text {a }}$ del Capítulo III del Libro I del Código civil". Para una valoración de lo que supuso la Segunda República en orden a la secularización del matrimonio, cfr. Fernández-
} 
exigió una prueba rigurosa de la acatolicidad el sistema fue de matrimonio civil subsidiario; mientras que cuando aquélla se flexibiliza nos encontramos en la práctica con un sistema de matrimonio civil facultativo, en el que los cónyuges podían elegir libremente entre el matrimonio canónico y el matrimonio civil (eso sí, para poder acceder a este último tendían que manifestar al encargado del Registro civil que no profesaban la religión católica) ${ }^{28}$.

A lo largo de casi un siglo (1974-1981) el sistema matrimonial español se centra en el binomio matrimonio civil-matrimonio canónico, reconocido este último en todas las redacciones del Código como una realidad con sustantividad propia, y no sólo en el citado artículo 42, sino también en otros preceptos, igualmente significativos, como el que abre el capítulo dedicado al matrimonio canónico (art. 75) y el que se refiere a la jurisdicción canónica (art. 80). Este rasgo característico quedará subrayado con mayor fuerza todavía en las modificaciones introducidas en los citados preceptos por la Ley de 24 de abril de $1958^{29}$, dictada para adecuar la redacción del Código civil a lo establecido en el artículo 42 del Concordato 27 de agosto de 1953, entre la Santa Sede y el Estado español ${ }^{30}$. En definitiva, durante este período el Estado reconoce efectos civiles

Coronado González, Ana, El proceso de secularización del matrimonio,Centro de Estudios Políticos y Constitucionales, Madrid, 2004, pp. 81-109.

${ }^{28}$ Cfr. la síntesis de De Fuenmayor, Amadeo, "La crisis del sistema español de matrimonio civil supletorio", en VV.AA., Rechtsgeschichte und Rechts dogmatik: Festschrift Hermann Eichler,Wien-New York, 1997, pp. 197-212; y de Dízz-PICAzo, Luis; Gullón, Antonio, Sistema de Derecho Civil, volumen IV, Derecho de familia. Derecho de sucesiones, Tecnos, Madrid, 1978, pp. 71-78. Para una exposición más pormenorizada me remito a IBÁN, Iván Carlos, "El término 'profesar la religión católica' en las resoluciones de la Dirección General de los Registros y del Notariado", Ius Canonicum, 1980, pp. 125-147; e ídem, "Calificación jurisprudencial del sistema matrimonial español (1938-1978)", Anuario de Derecho Civil, 1981, pp. 259-369.

${ }^{29}$ En el caso del artículo 42 del Código civil la expresión inicial "dos formas de matrimonio" es sustituida por la inequívoca "dos clases de matrimonio", sin posibilidad alguna de confusión. Algo semejante sucede con el artículo 75 del Código civil, que establece una remisión formal al ordenamiento canónico ("el matrimonio canónico, en cuanto se refiere a su constitución, validez y, en general, a su reglamentación jurídica, se regirá por las disposiciones de la Iglesia católica") mejorando la primitiva remisión material "los requisitos, forma y solemnidades para la celebración del matrimonio canónico se rigen por las disposiciones de la Iglesia Católica y del Santo Concilio de Trento, admitidas como Leyes del Reino"). Otro tanto ocurre con la nueva redacción del artículo 80 del Código civil que no sólo supera en precisión a su precedente sino también al artículo 24 del Concordato del que traía causa, cuando determina que "el conocimiento de las causas sobre nulidad y separación de los matrimonios canónicos, sobre dispensa del matrimonio rato y no consumado y sobre uso y aplicación del privilegio paulino, corresponde exclusivamente a la jurisdicción eclesiástica, conforme al procedimiento canónico, y sus sentencias y resoluciones tendrán eficacia en el orden civil, a tenor del artículo 82"; esto es, "en virtud de comunicación canónica de las sentencias o resoluciones, o a instancia de quien tenga interés legítimo y presente el oportuno testimonio" (art. 82).

30 "1. El Estado Español reconoce la competencia exclusiva de los Tribunales y Dicasterios eclesiásticos en las causas referentes a la nulidad del matrimonio canónico y a la separación de los cónyuges, en la dispensa del matrimonio rato y no consumado y en el procedimiento relativo al Privilegio Paulino.- 2. 
al matrimonio canónico tal y como lo regula la Iglesia Católica, con remisión formal a sus normas sobre capacidad, consentimiento y forma, e igualmente reconoce la eficacia civil de las sentencias y otras resoluciones eclesiásticas en materia de separación, nulidad y disolución de dicho matrimonio.

Estamos, por tanto, en presencia de dos realidades sustantivas, dos formas en el sentido tradicional que tiene esta expresión en el Derecho historico español, como equivalente a clases, y no ante un solo matrimonio con dos formas de celebración, una canónica y otra civil. Cuestión distinta es que, como ya sucediera con la Ley de 1870, el matrimonio civil sigue inspirándose en el modelo canónico, cuya estructura jurídica básica y líneas fundamentales reproduce el Código civil. El paralelismo con la normativa canónica resulta evidente a propósito de la capacidad de los contrayentes, tanto en lo que se refiere a los impedimentos y a su posible dispensa, como a los requisitos de consentimiento y forma, y lo mismo ocurre con las correlativas causas de nulidad por esos capítulos, así como con las causas de separación del matrimonio civil ${ }^{31}$. Natural-

Incoada y admitida ante el Tribunal eclesiástico una demanda de separación o de nulidad, corresponde al Tribunal civil dictar, a instancia de la parte interesada, las normas y medidas precautorias que regulen los efectos civiles relacionados con el procedimiento pendiente.- 3. Las sentencias y resoluciones de que se trate, cuando sean firmes y ejecutivas serán comunicadas por el Tribunal eclesiástico al Tribunal civil competente, e1 cual decretará lo necesario para su ejecución en cuanto a efectos civiles y ordenará -cuando se trate de nulidad, de dispensa "super rato" o aplicación del Privilegio Paulino- que sean anotadas en el Registro del Estado Civil al margen del acta de matrimonio.- 4. En general todas las sentencias, decisiones en vía administrativa y decretos emanados de las Autoridades eclesiásticas en cualquier materia dentro del ámbito de su competencia, tendrán también efecto en el orden civil cuando hubieren sido comunicados a las competentes Autoridades del Estado, las cuales prestarán, además, el apoyo necesario para su ejecución".

${ }^{31}$ En los artículos 83 y 84 C.c. encontramos, respectivamente, la mayor parte de los impedimentos matrimoniales absolutos y relativos. Entre los primeros figuran el impedimento de edad (14 años en el varón y 12 años en la mujer), de impotencia física para la procreación (absoluta o relativa, antecedente, patente, perpetua e incurable), de orden sagrado y de voto solemne (de castidad en orden religiosa) y de vínculo matrimonial; y entre los segundos encontramos los impedimentos de parentesco (de consanguinidad y de afinidad, tanto legítima como natural, y de adopción) y el de crimen o conyugicidio. El cuadro se completa con el artículo 101, que incluye el impedimento de rapto (mientras la raptada esté en poder del raptor). En cuanto a los requisitos relativos al consentimiento, éstos son el pleno ejercicio de la razón al tiempo de contraer matrimonio (art. 83, 2. ${ }^{\circ}$ ) y la ausencia de error en la persona, coacción o miedo grave (art. 101,.$^{\circ}$ ). En cuanto a la forma, para la validez del matrimonio civil se exige que se celebre con la intervención del Juez municipal competente o el de que en su lugar deba autorizarlo, y en presencia de dos testigos mayores de edad y sin tacha legal (art. 101, 4. ${ }^{\circ}$ a art. 100). Asimismo, se regula el matrimonio por poder (art. 87) y el matrimonio in articulo mortis (arts. 93-95). Por lo demás, se prevé el régimen de dispensas de los impedimentos (art. 85) y la posible convalidación automática del matrimonio en el caso de impúberes (si un día después de haber alcanzado la pubertad legal hubieran vivido juntos sin haber reclamado en juicio contra la validez o si la mujer hubiera concebido antes de la pubertad legal o de entablarse la reclamación) (art. 83, 1. ${ }^{\circ}$ ); y también se establece la caducidad de la acción y la convalidación del matrimonio si los cónyuges hubieran vivido juntos seis meses después de desvanecido el error o de haber cesado la fuerza o la causa del miedo, o de haber recobrado la libertad la raptada sin haber interpuesto en ese plazo demanda de nulidad (art. 102). 
mente siguen existiendo algunas diferencias relevantes con el originario modelo canónico en relación a la convalidación automática que prevé el Código civil y a sus silencios respecto a la relevancia de la simulación y de la condición en el consentimiento matrimonial ${ }^{32}$.

En definitiva, puede afirmarse que la regulación del matrimonio civil que ofrece el Código desde sus primeras redacciones, y a lo largo de la mayor parte del siglo XX, se inscribe dentro de lo que puede calificarse de secularización de la legislación matrimonial o secularización de las nupcias, en la medida en que admite la posibilidad de contraer matrimonio prestando el consentimiento en presencia de funcionarios civiles y sujetándose a leyes civiles. Pero todavía no estamos ante una secularización de la institución matrimonial o del matrimonio propiamente dicho, pues el matrimonio civil conserva los contenidos esenciales de la institución natural, que el Derecho canónico asume y protege, entre los que se incluye señaladamente la indisolubilidad ${ }^{33}$. Y es que, como afirmó Sancho Rebullida, "lo cierto es que, para que el matrimonio civil sea propiamente matrimonio (y no un concubinato legalizado), debe reunir los presupuestos-diversidad de sexos, exogamia-, cumplir los fines -procreación y educación de la prole, amor conyugal- y responder a los caracteres adecuados al mejor cumplimiento de tales fines -unidad e indisolubilidad- propios del matrimonio canónico en cuanto institución natural. En otro caso, el Derecho positivo, al contradecir tales presupuestos, fines y caracteres, contradiría en realidad el Derecho natural"34.

\section{REFORMAS Y TRANSFORMACIONES DEL MATRIMONIO (1981-2007)}

La Constitución española de 1978 desencadena un proceso de renovación del ordenamiento jurídico, que también afecta al matrimonio ${ }^{35}$. Su aprobación va a llevar consigo la sustitución formal del sistema de matrimonio civil subsidiario por el de matrimonio civil facultativo ${ }^{36}$. Reconoce el derecho del

\footnotetext{
${ }^{32}$ El Código tampoco contempla el matrimonio civil celebrado en secreto, aunque, como ya he mencionado, se introdujo en 1906. Posteriormente, se incorporó a la Ley del Registro civil de 8 de junio 1957 (arts. 70, 78 y 79) y también fue objeto de regulación por el Reglamento del Registro civil de 14 de noviembre de 1958 (arts. 266-270). Cfr. sobre el particular, GARCía, El vínculo, cit. nota n. 24, pp. 211-213; y Pere Raluy, José, Derecho del Registro Civil, tomo Il, Aguilar, Madrid, 1962, pp. 741-743.

${ }_{33}$ Cfr. González del Valle, José María, "Mis perplejidades sobre el matrimonio", en Instituto Martín de Azpilcueta, Escritos en honor de Javier Hervada, volumen especial de lus Canonicum, 1999, p. 554.

${ }^{34}$ Sancho Rebullida, Francisco de Asís, "Artículos 83 a107", en Albaladejo, Manuel (Dir.), Comentarios al Código Civil y Compilaciones Forales, Tomo II, Editorial de Derecho Privado-Editoriales de Derecho Reunidas, Madrid, 1978, p. 279.

${ }_{35}$ Para una visión de conjunto, cfr. FerRer OrTiz, Javier, “La familia en la experiencia constitucional española: declaraciones de principio y realidad normativa", lus Canonicum, 1994, pp. 459-482.

${ }^{36}$ Así lo declaró, aun antes de la entrada en vigor de la Constitución, la Dirección General de los Registros y del Notariado, en su Instrucción de 26 de diciembre de 1978: interpretando los artículos
} 
hombre y de la mujer a contraer matrimonio en pie de igualdad e indirectamente ampara la monogamia y la heterosexualidad (art. 32.1) ${ }^{37}$. También dirige un mandato al legislador ordinario para que regule las formas de matrimonio (art. 32.2), expresión que en su amplitud y en conexión con otros preceptos del mismo texto legal (arts. 14, 16 y 149.1.8. ${ }^{a}$ ) posibilita la instauración de un sistema matrimonial facultativo, compuesto y de formación progresiva, en el que junto al matrimonio civil puedan concurrir otros matrimonios religiosos ${ }^{38}$. Todo ello unido el deliberado silencio del constituyente respecto al divorcio, hizo que el matrimonio canónico siguiera siendo reconocido civilmente con sustantividad propia.

Esta situación, en lo que al matrimonio canónico se refiere, cambió ligeramente mediante el Acuerdo sobre asuntos jurídicos, de 3 de enero de 1979, entre la Santa Sede y el Estado español (AJ), que junto a otros cuatro Acuerdos concordatarios más (tres de esa misma fecha y otro anterior, de 1976) derogaron el Concordato de $1953^{39}$.

No obstante, la situación descrita va a experimentar un cambio radical, aunque paulatino, mediante una serie de reformas del matrimonio o relacionadas con él, que acabarán transformándolo por completo. Este proceso puede

32.1 y 16.2 de acuerdo con los principios de aconfesionalidad o laicidad del Estado (art. 16.3) y de no discriminación por razón de religión (art. 14), afirma que "todos pueden acudir a la celebración del matrimonio civil con plena libertad de elección y sin necesidad de hacer declaración alguna sobre su religión, respecto de la cual el Juez o Cónsul no pueden preguntar". En consecuencia, concluye que han de entenderse modificados los artículos 42 y 86 del Código civil y concordantes, de tal manera que "Ios Jueces y Cónsules encargados de los Registros civiles deben autorizar los matrimonios civiles de las personas que lo deseen sin indagación ni declaración alguna sobre las ideas religiosas de los contrayentes". El hecho de que el resto de texto codicial permaneciera inalterado, en particular su artículo 75, permitieron adscribir el sistema al modelo latino, por cuanto el matrimonio canónico seguía siendo reconocido como un todo por el ordenamiento español. Sobre la clasificación de los distintos sistemas matrimoniales y sus características, cfr. FeRRER OrTIz, Javier, Matrimonio religioso y ordenamiento estatal, cit., pp. 5-7.

${ }^{37}$ Así lo entendió toda la doctrina y así se ha venido entendiendo pacíficamente hasta el año 2005, en que se aprobó la ley que reconoce el matrimonio entre personas del mismo sexo, de la que me ocuparé más adelante.

${ }^{38}$ Cfr. Ferrer Ortiz, Javier, El matrimonio canónico en el ordenamiento español, Eunsa, Pamplona, 1986, pp. 30-40.

${ }^{39}$ El texto mencionado supuso la implantación de un nuevo sistema matrimonial facultativo con las siguientes características: $1{ }^{a}$ ) el Estado reconoce efectos civiles al matrimonio canónico desde la celebración, aunque supedita su pleno reconocimiento a que se inscriba en el Registro civil (art. 6.1 y 2, y protocolo final AJ); 2.a) sólo prevé la eficacia civil de las resoluciones eclesiásticas de nulidad de matrimonio y de disolución de matrimonio rato y no consumado si se declaran ajustadas al Derecho del Estado (art. $6.2 \mathrm{AJ}) ; 3 .^{\mathrm{a}}{ }^{\text {) }}$ no se pronuncia sobre si reconoce o no la competencia exclusiva de la Iglesia católica sobre los matrimonios canónicos; y $4 .{ }^{a}$ ) tratando de evitar que una futura ley introdujera civilmente el divorcio para todo matrimonio, la Santa Sede "recuerda a quienes celebren matrimonio canónico la obligación grave que asumen de atenerse a las normas canónicas que lo regulan y, en especial, a respetar sus propiedades esenciales" (art. 6.3 AJ). Cfr. ibidem, pp. 40-56. 
inscribirse dentro un panorama más amplio que se inicia en los años 1960 en los países nórdicos, más principalmente en Suecia, calificado entonces como laboratorio social europeo ${ }^{40}$, y que se irá extendiendo a otros países de Occidente ${ }^{41}$. Entre sus principales rasgos podemos destacar la tendencia a invocar la realidad social como motor de los cambios ${ }^{42}$ y a convertir las circunstancias sociales en criterio ético indiscutible ${ }^{43}$. También ocupa un lugar relevante el recurso al libre desarrollo de la personalidad ${ }^{44}$ para fundamentar la conversión de los deseos de unos (pocos o muchos) en derechos de todos ${ }^{45}$.

${ }^{40}$ Con esta expresión se alude al carácter pionero que adoptó este país al aprobar leyes novedosas que
luego serían secundadas por otros Estados, tanto en Europa como en América. Sin embargo, como ya
señalara Sundberg en 1980, vistas las consecuencias, algunas reformas del Derecho de familia pueden
ser descritas como un viaje a ninguna parte: viaje en el que al cabo de un tiempo el viajero descubre
con sorpresa, cuando ya es demasiado tarde, que ha adquirido el billete por error, que es extremada-
mente caro y que el viaje de vuelta no está incluido en el precio (cfr. SunDBerg, Jacob W. F., "Un regard
sur la situationactuelle en Scandinavie: le droit de la familledans la tourmente", en C.N.R.S., Mariage
et Famille en question, Paris, 1980, citado porTrabuccH,, Antonio, Pas par cettevoie s'il vous plait!, en Rivista di Diritto Civile, 1981, I, p. 329).

${ }^{41}$ Para una visión de conjunto, sintética pero sustancialmente completa, me remito a GARCía CANTERO, Gabriel, ¿Unidad o pluralidad de modelos matrimoniales?, Zaragoza 2003.

${ }^{42}$ Pero, como recuerda García Cantero, los datos sociales tienen un límite: "Ex facto non oriturius. La norma no puede ser mera traducción a términos jurídicos de lo que ha sucedido o está sucediendo en la vida real. Sobrarían, en tal caso, los órganos legislativos y todo sería costumbre o uso social, o, mejor aún, mero hecho jurídico, convertido automáticamente en regla de derecho" (GARCía CANTERO, Gabriel, "Artículos 42 a107", enAlbaladejo, Manuel (Dir.), Comentarios al Código Civil y Compilaciones Forales, $2^{\text {a }}$ Edición, Tomo II, Editorial Revista de Derecho Privado-Editoriales de Derecho Reunidas, Madrid, 1982, p. 8). Bien es cierto que el Código civil establece que "las normas se interpretarán según el sentido propio de sus palabras, en relación con el contexto, los antecedentes históricos y legislativos, y la realidad social del tiempo en que han de ser aplicadas" (art. 3.1). Sucede, sin embargo, como explica Pérez Álvarez con precisión, que del tenor del precepto se desprende que la realidad social no es objeto de interpretación, por lo que no puede servir para corregir el sentido de una norma más allá de su espíritu y finalidad, reduciendo así las posibilidades del arbitrio judicial en la labor hermenéutica (cfr. Pérez Álvarez, Miguel Ángel, Interpretación y jurisprudencia: estudio del artículo 3.1 del Código Civil, Aranzadi, Pamplona, 1994, pp. 66-68).

${ }^{43}$ Cfr. Ollero, Andrés, "Los derechos humanos entre el tópico y la utopía", Persona y Derecho, 1999, p. 163.

${ }^{44}$ La Constitución española afirma que "el libre desarrollo de la personalidad", junto a "la dignidad de la persona, los derechos que le son inherentes (...), el respeto a la ley y a los derechos de los demás son fundamentos del orden político y de la paz social" (art. 10.1). El precepto se inspira en el artículo 2.1 de la Ley de Bonn de 1949 ("Toda persona tiene el derecho al libre desarrollo de su personalidad siempre que no viole los derechos de otros ni atente contra el orden constitucional o la ley moral"), aunque una expresión similar se encuentra ya en el artículo 22 de la Declaración Universal de Derechos Humanos de 1948 " "Toda persona como miembro de la sociedad, tiene derecho a la seguridad social, y a obtener, mediante el esfuerzo nacional y la cooperación internacional, habida cuenta de la organización y los recursos de cada Estado, la satisfacción de los derechos económicos, sociales y culturales, indispensables a su dignidad y al libre desarrollo de su personalidad").

${ }^{45}$ Aunque, en rigor, no parece que una pretensión de este género pueda sustentarse en los textos mencionados en la nota anterior, esto es lo que viene sucediendo en España en las leyes recientes 
Entramos así en lo que se ha denominado la dinámica de la secularización, "entendida como superación de toda ilusión metafísica y de todos los límites (y tabúes) que semejante ilusión impone al sujeto"46. En ella, el matrimonio civil intenta asimilar datos sociológicos dispares e incorporarlos a los textos legislativos, y en esta situación de cambio permanente pierde la condición de categoría jurídica más o menos objetivable que mantenía hasta ahora para adoptar la condición de "polisistema mutante que, en realidad, no es ni parece pueda ser modelo sino a lo más expectativa" ${ }^{\prime 4}$.

Pero no es éste lugar para detenerme en la exposición pormenorizada de los factores del cambio experimentado por el Derecho de familia en Occidente ${ }^{48}$,

más controvertidas. Por eso mismo conviene recordar una circunstancia especialmente significativa como es el hecho de que el artículo 22 de la Declaración Universal trata del derecho a la seguridad social y a obtener la satisfacción de los derechos económicos, sociales y culturales; y es en este contexto -y no en otro- en el que en su redacción final menciona la dignidad de la persona y el libre desarrollo de su personalidad, con el fin de hacer más independiente la afirmación contenida en este artículo (cfr. Verdoodt, Albert, Declaración Universal de los Derechos del Hombre. Nacimiento y significado, Mensajero, Bilbao, 1966, pp. 205-211). Algo parecido sucede cabalmente con el artículo 10.1 de la Constitución española, resultando igualmente ilustrativo que uno de sus primeros comentadores dijera que el libre desarrollo de la personalidad tiene carácter suprapositivo: es una afirmación valorativa que ilumina todo el texto constitucional y que se modula en cada derecho y libertad concreto; $y$, junto a la dignidad de la persona humana, constituye la esencia de los derechos y libertades básicos concebidos como expresión de la racionalidad y de la sociabilidad (LUCAS VERDú, Pablo, "De los derechos y deberes fundamentales", en Autores Varios, Constitución Española. Edición comentada, Centro de Estudios Constitucionales, Madrid, 1979, pp. 39-41).

${ }^{46}$ D'Agostino, Francesco, Filosofía de la familia, Rialp, Madrid, 2006, p. 36.

${ }^{47}$ Navarro Valls, Rafael, Matrimonio y Derecho, Tecnos, Madrid, 1994, p. 37. En el mismo lugar el autor enumera, siguiendo a D'Agostino y a Del Noce, las consecuencias culturales y sociales de la secularización: "la escisión de la sexualidad respecto a la procreación, una crítica frontal a la familia de base conyugal como lugar de represión; la exaltación de la vitalidad como valor más allá de toda limitación "burguesa", la emancipación de la conciencia de la protección externa de la ley o el acogimiento de una inabarcable subjetividad conectada con una peculiar visión de los derechos fundamentales que plantea el desafío de una espiral de reivindicaciones infinitas de incierto destino jurídico" (Ibidem). El propio D'Agostino las menciona de nuevo en su más reciente Filosofía de la familia, cit., p. 36, citando a Del Noce, Augusto, L'epoca della secolarizzazione,Giuffrè, Milano, 1970.

${ }^{48}$ Entre las publicaciones que se han ocupado de este proceso destacaría la completa panorámica de la familia que ofrece Martínez de AguirRe,Carlos, Diagnóstico sobre el Derecho de Familia, Rialp, Madrid, 1996; la visión de conjunto del modelo matrimonial de Occidente desde su formación hasta su estado actual Ilevada a cabo por Navarro Valls, Rafael, Matrimonio y Derecho,Tecnos, Madrid 1994 (ya citada); y las acertadas y sugerentes reflexiones que desde una perspectiva iusfilosófica formula Pedro Juan Viladrich, "El matrimonio y la familia en el marco de la crisis de los sistemas jurídicos matrimoniales. Un reto para la canonística actual", VV.AA., Chiesa e Statonei sistemi giuridici contemporanei, VIII Congresso Internazionale di Diritto Canonico, Lublin, 1993, pp. 1-52; e ídem, "La definición del matrimonio", en VILADrICH, Pedro Juan et alii (dirs.), El matrimonio y su expresión canónica ante el III Milenio, X Congreso Internacional de Derecho Canónico, Eunsa, Pamplona 2000, pp. 205-312 (ponencia publicada también en dos volúmenes: P. J. VILADRICH, El modelo antropológico del matrimonio, Rialp, Madrid, 2001 e ídem, El ser conyugal, Rialp, Madrid, 2001). 
sino para ocuparme de las principales leyes aprobadas en España en relación al matrimonio civil, y que podemos situar hasta ahora en el arco temporal comprendido entre 1981 y 2007.

La primera de ellas es la Ley 30/1981, de 7 de julio, por la que se modifica la regulación del matrimonio en el Código civil y se determina el procedimiento a seguir en las causas de nulidad, separación y divorcio ${ }^{49}$. Esta ley será comúnmente denominada Ley del divorcio, por ser éste sin duda su aspecto más relevante y novedoso, y el de mayor trascendencia en cuanto a la configuración civil del matrimonio. En efecto, introduce el divorcio con carácter general, para todo matrimonio y con carácter retroactivo: "el matrimonio se disuelve, sea cual fuere la forma y el tiempo de su celebración (...), por el divorcio" (art. 85 C.c.). En cuanto al sistema que introduce, no se trata de un piccolo divorzio dei casi pietosi ${ }^{50}$, ni de un divorcio sanción o divorcio por culpa, sino de un divorcio remedio, cuyas causales giran principalmente en torno al cese efectivo de la convivencia conyugal durante unos plazos que, dependiendo de las circunstancias, oscilan entre uno a cinco años (art. 86 C.c.).

Junto a la eliminación de la indisolubilidad como rasgo propio del matrimonio, la ley también es importante porque reduce y condiciona el reconocimiento del matrimonio canónico y de los pronunciamientos eclesiásticos sobre él, colisionando con lo establecido específicamente en el Acuerdo sobre asuntos jurídicos de $1979^{51}$. Otro extremo de interés es que la ley prevé la incorporación al sistema de otros matrimonios religiosos con efectos civiles, al disponer que "el consentimiento matrimonial podrá prestarse en la forma prevista por

\footnotetext{
${ }^{49} \mathrm{Cfr}$. la sintética exposición que de ella hizo en clave de modelo matrimonial José Antonio Álvarez Caperochipi, "En torno al origen y significado del matrimonio civil”, en La Ley. Revista jurídica argentina de doctrina, jurisprudencia y bibliografía, № 199, de 27 de agosto de 1984, pp. 1-3.

${ }^{50}$ Cfr. De Fuenmayor, Amadeo, "Slogans divorcistas", en HervadA, Javier et alii, Divorcio, Eunsa, Pamplona, 1977, pp. 167-170.

${ }^{51}$ En el momento constitutivo o de la celebración se reconoce que "el matrimonio celebrado según las normas del Derecho canónico (...) produce efectos civiles" (art. 60 C.c.), "desde su celebración" (art. 61 C.c.). Sin embargo, este reconocimiento de su realidad sustantiva tiende a difuminarse y a desaparecer en el momento registral o de la inscripción en el Registro civil, porque el Estado la denegará al matrimonio religioso que no reúne los requisitos que para su validez se exigen en el Código civil (art. 63.2 C.c.), en cuyo caso no alcanzaría el pleno reconocimiento de efectos civiles (art. 63.1 C.c.). La situación se agrava en el momento crítico, porque la Ley de 1981 declara aplicables las causas civiles de nulidad y disolución (además de las de separación) a todo matrimonio sin excepción (art. 85 C.c.), y también somete la eficacia civil de las resoluciones eclesiásticas al cumplimiento de una serie de requisitos civiles que apreciará in casu el juez de primera instancia (art. 80 C.c. y, por remisión, art. 954 de la Ley de Enjuiciamiento Civil de 1888). Cfr. FerRer Ortiz, Javier, El matrimonio canónico en el ordenamiento español, cit., pp. 65-132.
} 
una confesión religiosa inscrita, en los términos acordado por el Estado o, en su defecto, autorizados por la legislación de éste" (art. 59 C.c.) ${ }^{52}$.

En un plano menor, pero también innovador, se introduce la declaración de fallecimiento como causa de disolución del matrimonio, en los mismos términos que el divorcio (art. 85), alejando la regulación de la canónica y de la civil precedente ${ }^{53}$. Asimismo resulta relevante y significativa la supresión del impedimento de impotencia, que indirectamente supone el rechazo de la generación (y educación) de la prole como uno de los fines esenciales del matrimonio, mientras que su posible relevancia en materia de nulidad, a través del error "en aquellas cualidades que, por su entidad, hubieren sido determinantes de la prestación del consentimiento" (art. 73, 4. a), inserta definitivamente la impotencia en el ámbito de la subjetividad de los contrayentes.

En otro orden de cosas, es preciso apuntar la existencia de una serie de leyes que inciden indirectamente en el matrimonio, en la medida en que materializan la escisión entre sexualidad, procreación y matrimonio. Se trata de la Ley 35/1988, sobre Técnicas de reproducción asistida, de las que podrá ser receptora y usuaria toda mujer, tanto si está casada como si no lo está, y donde se regula tanto la inseminación artificial homóloga (con semen del marido o

\footnotetext{
${ }^{52}$ Posteriormente, las Leyes 24, 25 y 26/1992, de 10 de noviembre, por las que se aprobaron, respectivamente, los Acuerdos de cooperación con la Federación de Entidades religiosas de España (FEREDE), con la Federación de Comunidades Judías de España (FJC) y con la Comisión Islámica de España (CIE), supusieron la efectiva incorporación de sus matrimonios al sistema. En el artículo 7.1 de cada uno de esos convenios "se reconocen los efectos civiles del matrimonio celebrado ante los ministros de culto de las Iglesias pertenecientes a la FEREDE", "del matrimonio celebrado según la propia normativa formal israelita" y "del matrimonio celebrado según la forma religiosa establecida en la Ley islámica". No obstante, la doble exigencia del expediente civil y del certificado de capacidad matrimonial, previos a la celebración religiosa de esos matrimonios (o a su inscripción en un caso pretendidamente excepcional del matrimonio islámico), así como la ausencia de cualquier tipo de eficacia civil de las resoluciones confesionales de nulidad y disolución de esos matrimonios, permiten afirmar que en puridad estamos ante matrimonios civiles celebrados en forma religiosa, por regirse en sus aspectos sustantivos por las normas estatales. Sucede, además, que como el consentimiento deberá prestarse ante el ministro de culto oficiante de la ceremonia o ante el dirigente religioso o imán (según los casos) y al menos dos testigos mayores de edad, parece incluso que la forma de celebración es civil (eso sí ocupando el representante de la confesión el lugar del representante del Estado) y sólo se reconoce el rito o ceremonia religiosa de prestación del consentimiento. Cfr. FerRer OrTiz, Javier, “El sistema matrimonial español”, en Otaduy, Jorge (pres.), Tratado de Derecho Eclesiástico, Eunsa, Pamplona, 1994, pp. 968-990.

${ }^{53}$ Hasta la reforma, la declaración no bastaba por sí sola para que el cónyuge presente pudiera contraer matrimonio (art. 195.3 C.c), pero a partir de ella se concibe como causa que disuelve el matrimonio y no como presunción iuris tantum de fallecimiento del cónyuge que permitía al supuestamente viudo acceder a nuevas nupcias (tal y como sucede en Derecho canónico, c. 1707 CIC 1983), sin perjuicio de que si luego se demostraba que el cónyuge declarado premuerto vivía cuando se celebró ulterior matrimonio, éste debía declararse nulo por impedimento de vínculo. A partir de la reforma de 1981, el declarado fallecido pierde la condición de casado y si reaparece no la recupera, mientras que desde su regreso o desde la declaración de no haber muerto recobrará sus bienes en el estado en que se encuentren o su equivalente, así como las rentas, frutos y productos obtenidos con los bienes de su sucesión a partir de entonces (art. 197 C.c.).
} 
de la pareja) o heteróloga (con semen de donante), así como la fecundación in vitro con transferencia de embriones ${ }^{54}$.

Otro grupo de disposiciones que inciden más directamente en el concepto legal del matrimonio tienen como denominador común el establecimiento de una cierta equiparación entre la unión de hecho more uxorio y el matrimonio. Comenzó a resultar habitual que, con ocasión de la regulación de distintas materias, cada vez que el legislador menciona al cónyuge, añade una cláusula del estilo "o persona a quien se halle ligado de forma estable por análoga relación de afectividad" ${ }^{\prime \prime 5}$, y lo mismo sucede con las referencias al matrimonio, que suelen ir acompañadas por la fórmula "o por vivir maritalmente con otra persona" ${ }^{\prime \prime 6}$, o por otras equivalentes como "o conviviere maritalmente con persona distinta del progenitor" ${ }^{\prime \prime}$, "o pareja unida de forma permanente por relación de afectividad análoga a la conyugal"58.

En la misma dirección y en simultáneo van a ir apareciendo una serie de disposiciones reguladoras de las uniones de hecho, heterosexuales y homosexuales. Inicialmente se trata de disposiciones de carácter local, siguiendo el ejemplo del Ayuntamiento de Vitoria, que crea un Registro municipal de uniones de hecho, de carácter administrativo, en $1994^{59}$. En poco tiempo son las Comunidades Autónomas las que empiezan a legislar sobre la materia empezando por la Ley 10/1998 de 15 de julio, de uniones estables de pareja, aprobada por el Parlamento de Cataluña, y la Ley 6/1999, de 26 de marzo de

${ }^{54}$ Junto con esta norma reaprobó también la Ley 42/1988, de 28 de diciembre, de Donación y utilización de embriones y fetos humanos o de sus células, tejidos u órganos. Unos años más tarde se aprobó la Ley 45/2003, de 21 de noviembre, por la que se modifica la Ley 35/1988, sobre Técnicas de reproducción asistida, actualizándola y tratando de reducir la generación y acumulación de embriones, y la tasa de embarazos múltiples. Sin embargo, poco después se dictó la Ley 14/2006, de 26 de mayo, sobre Técnicas de reproducción humana asistida, mucho más permisiva que las dos anteriores a las que deroga.

${ }^{55}$ La expresión se encuentra en el Código penal, aprobado por Ley orgánica 10/1995, de 23 de noviembre, cuando delimita la circunstancia mixta que puede atenuar o agravar la responsabilidad según la naturaleza, los motivos y los efectos del delito (art. 23) y la eximente de determinados encubridores (art. 454). Esta doble equiparación ya figuraba en el precedente Código penal, reformado por Ley 8/1983, de 25 de junio, entonces en los artículos 11 y 18, respectivamente.

${ }^{56}$ Fórmula empleada por el Código civil para referirse a una causa que, junto a la celebración de un nuevo matrimonio por parte del acreedor, determina la extinción del derecho a la pensión por desequilibrio económico a favor del cónyuge en caso de separación o divorcio (art. 101 C.c.).

${ }^{57}$ Circunstancia equiparable a la celebración de nupcias por parte del progenitor, que faculta a los hijos mayores de dieciséis años a pedir su emancipación (art. 320.1 C.c.).

${ }^{58}$ Con estas palabras la Ley $21 / 1987$, de 11 de noviembre, establece que las referencias a la capacidad de los cónyuges para adoptar simultáneamente a un menor serán aplicables al hombre y la mujer integrantes de una unión de esas características (disposición adicional 2. ${ }^{a}$ ).

${ }^{59}$ Cfr. Decreto del Ayuntamiento de Vitoria, de 28 de febrero de 1994, en Boletín Oficial del País Vasco, 58, de 24 de marzo de 1994. 
1999, relativa a parejas estables no casadas, aprobada por las Cortes de Aragón, a las que siguen muchas otras ${ }^{60}$. En una primera etapa, la mayor parte de estas leyes (a excepción de la Ley foral 6/2000, de 3 de julio, de igualdad jurídica de las parejas estables, aprobada por el Parlamento de Navarra ${ }^{61}$ ) distinguían entre las uniones de hecho heterosexuales y las homosexuales, restringiendo a aquellas la posibilidad de adoptar. No obstante, en una segunda etapa pasaron a eliminar la distinción y, con ella, la restricción ${ }^{62}$.

El examen detenido de cualquiera de estas leyes permite advertir que reproducen en cierto modo el mismo esquema que el matrimonio civil toma del matrimonio canónico: la unión de hecho legalizada, es decir, la que reúne los requisitos fijados por el legislador autonómico, mantiene los tres pilares del matrimonio (capacidad, consentimiento y forma) y sus tres momentos (constitutivo, registral y crítico).

Si nos fijamos, por ejemplo, en la Comunidad Autónoma de Aragón, la Ley 6/1999, de 26 de marzo, relativa a las parejas estables no casadas ${ }^{63}$, comprobamos que para poder constituir la unión de hecho es necesario que las personas sean mayores de edad (art. 1), no pueden estar ligados por vínculo matrimonial (art. 4.1), ni ser parientes en línea recta por consanguinidad o adopción (art. 4.2), ni colaterales por consanguinidad o adopción hasta segundo grado (art. 4.3), ni formar pareja estable con otra persona (art. 4.4). Encontramos así unos impedimentos (edad, vínculo, parentesco de consanguinidad y de adopción) y una exigencia de unidad de la unión. En cuanto al consentimiento se exige,

\footnotetext{
${ }^{60}$ Estas leyes han sido posibles porque entre las materias sobre las que el Estado tiene competencia exclusiva se incluyen, entre otras, las "relaciones jurídico-civiles relativas a las formas de matrimonio" (art. 149, 1, 8. ${ }^{a}$ ), expresión tradicional y actual en el Derecho español para aludir a las clases o aspectos sustantivos del matrimonio. El silencio de la Constitución respecto a las uniones de hecho, unida a la circunstancia de que posteriormente no se aprobara ninguna regulación general sobre ellas, posibilitó que las Comunidades Autónomas dictaran sus propias leyes y reglamentos. Cfr. Alonso Pérez, José Ignacio, El reconocimiento de las uniones no matrimoniales en la Unión Europea, Librería Bosch, Barcelona, 2007, que analiza las Leyes de las Comunidades Autónomas del Estado español sobre la materia.

${ }^{61}$ Artículo 8.1: "Los miembros de la pareja estable podrán adoptar de forma conjunta con iguales derechos y deberes que las parejas unidas por matrimonio" (en Boletín Oficial de Navarra, 82, de 7 de julio de 2000).

${ }^{62}$ Es el caso de Aragón, cuya Ley 2/2004, de 3 de mayo, de modificación de la Ley 6/1999, de 26 de marzo, relativa a parejas estables no casadas, elimina el término heterosexuales del artículo 10 ("Las parejas estables no casadas heterosexuales podrán adoptar conjuntamente"), con lo cual todas las parejas sin distinción podrán adoptar. De esta suerte la única distinción entre parejas heterosexuales y homosexuales que formulaba la Ley 6/1999 en su redacción inicial queda eliminada.

${ }^{63}$ Conviene advertir que esta ley ha estado vigente hasta el 23 de abril de 2011, fecha de la entrada en vigor del Decreto Legislativo 1/2011, de 22 de marzo, del Gobierno de Aragón, por el que se aprueba, con el título de "Código de Derecho Foral de Aragón", el Texto refundido de las Leyes civiles aragonesas. Los preceptos de la ley derogada se han convertido en los artículos 303 a 315 del Código de Derecho Foral de Aragón, sin que su contenido material haya experimentado variación alguna. Por este motivo, he preferido citarlos en el texto siguiendo la numeración que tenían en la Ley 6/1999.
} 
en principio, una manifestación de voluntad de constituir la unión en escritura pública o que se demuestre una convivencia ininterrumpida de dos años (art. 3) y se prohíbe someterla a plazo o a condición (art. 5.2), así que la unión debe ser estable, nota que figura en su propia denominación. Con esos requisitos la unión de hecho puede acceder al Registro específico del Gobierno de Aragón (art. 2). En cuanto al momento crítico, la pareja estable se extingue por la muerte o declaración de fallecimiento de uno de sus integrantes, de común acuerdo, por decisión unilateral, por separación de hecho de más de un año y por matrimonio de uno de sus miembros (art. 6.1). A la vista de lo anterior, la proximidad de requisitos con el matrimonio y, simultáneamente, el tono de menor exigencia que guarda respecto a éste, permite calificar en cierto modo a la unión de hecho legalizada como un matrimonio civil de segunda categoría.

El interés por estas uniones va a decrecer rápidamente con ocasión de la Ley 13/2005, de 1 de julio, por la que se modifica el Código civil en materia de derecho a contraer matrimonio. Como es sabido, su punto central es la adición de un segundo párrafo al artículo 44 del Código civil, del siguiente tenor: "El matrimonio tendrá los mismos requisitos y efectos cuando ambos contrayentes sean del mismo o de diferente sexo". En consecuencia, suprime la heterosexualidad como rasgo propio del matrimonio y con ello hace en buen parte superflua la reivindicación de los colectivos de gays y lesbianas cuando pedían el reconocimiento de las uniones de hecho y su equiparación al matrimonio, incluida la facultad de poder adoptar conjuntamente. Al cambiar radicalmente el concepto de matrimonio todo eso es posible.

Durante su tramitación la ley fue objeto de duras críticas y reservas en el ámbito jurídico y político, estando pendiente la resolución de un recurso de constitucionalidad contra ella ${ }^{64}$. Desde el punto de vista cualitativo o conceptual es evidente que se trata de una ley demoledora no sólo del matrimonio civil propio de la civilización occidental, sino también del matrimonio en general. Con todo, y como era de esperar, en el plano cuantitativo su incidencia ha

\footnotetext{
${ }^{64}$ El proyecto de ley recibió severas críticas por parte de las principales instancias jurídicas del país. Tanto el Consejo de Estado, en dictamen emitido por unanimidad el 26 de diciembre de 2004, como el Pleno del Consejo del Poder Judicial, en su dictamen aprobado el 26 de enero de 2005, como la Real Academia de Jurisprudencia y Legislación en su informe de 21 de febrero de 2005, manifestaron sus reservas acerca de la constitucionalidad del entonces proyecto. El Senado de la nación también se pronunció en contra, vetándolo y devolviéndolo al Congreso de los Diputados, que finalmente lo aprobaron. Y posteriormente, más de cincuenta diputados del Grupo Parlamentario Popular en el Congreso presentaron recurso de inconstitucionalidad con fecha de 28 de noviembre de 2005, sin que todavía se haya pronunciado el Tribunal Constitucional. Para una exposición de cierto detalle acerca de la Ley 13/2005, que aprueba el matrimonio entre personas del mismo seXo, cfr. FERRER OrTiz, Javier, "Las reformas del Derecho de Familia: ¿interés público o ingeniería social", en BLANCO, María et alii,lus et lura, Escritos de Derecho Eclesiástico y de Derecho Canónico en honor del profesor Juan Fornés, Comares, Granada, 2010, pp, 407-432; publicado también en la Argentina, en Revista de Derecho de Familia y de las Personas, № 8, septiembre 2010, pp. 67-84.
} 
sido mínima, lo que también confirma que se trata de una obra de ingeniería social ${ }^{65}$.

Paralelamente a esta norma se aprobó la Ley 15/2005, de 8 de julio, por la que se modifica el Código civil y la Ley de enjuiciamiento civil en materia de separación y divorcio. La relevancia mediática de la anterior hizo que ésta pasara casi desapercibida, aunque su trascendencia no es menor $y$, desde luego, su proyección cuantitativa no admite comparación alguna, como veremos. La ley en cuestión, invocando el libre desarrollo de la personalidad, introduce un sistema que puede calificarse de divorcio-repudio, unilateral y rápido, de ahí que se la denomina coloquialmente Ley del divorcio exprés. Deroga el sistema causal del artículo 86 del Código civil que, como ya vimos, pivotaba sobre el cese efectivo de la convivencia conyugal y el transcurso de unos plazos, y hacía de la separación un paso previo hacia el divorcio aunque no avocaba irremediablemente a él ${ }^{66}$.

El nuevo artículo 86 del Código civil dispone que "se decretará judicialmente el divorcio, cualquiera que sea la forma de celebración del matrimonio, a petición de uno solo de los cónyuges, de ambos o de uno con el consentimiento del otro, cuando concurran los requisitos y circunstancias exigidos en el artículo $81^{\prime \prime}$. Esto significa que para que se declare el divorcio bastará la voluntad de uno de ellos "una vez transcurridos tres meses desde la celebración del matrimonio", aunque "no será preciso el transcurso de este plazo (...) cuando se acredite la existencia de un riesgo para la vida, la integridad física, la libertad, la integridad moral o libertad e indemnidad sexual del cónyuge o de los hijos de ambos o de cualquiera de los miembros del matrimonio" (art. 81.2. ${ }^{\circ}$ C.c.).

Como cabía esperar esta ley ha producido un fuerte impacto desde el punto de vista cuantitativo, habida cuenta de que sus potenciales destinatarios son todos los matrimonios celebrados, y así lo han confirmado el número de divor-

\footnotetext{
${ }^{65}$ Durante los primeros seis meses transcurridos desde la entrada en vigor de la ley, entre el 3 de julio y el 31 de diciembre de 2005, se celebraron un total de 1.269 matrimonios entre personas del mismo sexo, mientras que en el mismo período se celebraron 119.459 matrimonios entre personas de diferente sexo, lo que significa que aquellos supusieron el 1,5\% del total de matrimonios. Los datos de los años sucesivos no ofrecen cambios relevantes: en 2006 los matrimonios entre personas del mismo sexo (4.313) representan el 2,0\% del total de matrimonios (207.766); en 2007 el 1,5\% (3.193 sobre un total de 204.772 matrimonios); en 2008 el 1,6\% (3.194 sobre un total de 197.216); en 2009 el 1,7\% (3.082 sobre un total de 177.144); y en 2010 el 2,0\% (3.583 sobre un total de 170.815). Cfr. Instituto Nacional de Estadística, Movimiento natural de la población, en http://www.ine.es/jaxi/menu.do?typ $\mathrm{e}=$ pcaxis\&path $=\% 2 \mathrm{Ft} 20 \% 2 \mathrm{Fe} 301 \&$ file=inebase \&L[visitado el 07/07/11] .

${ }^{66}$ La separación podía abrir a los cónyuges un plazo de reflexión en el que cabía la reconciliación; de hecho, según las estadísticas disponibles en 2004, al tiempo de la tramitación de la ley, un 35\% de las separaciones no terminaba en divorcio y en un $25 \%$ de los casos se producía la reconciliación (cfr. NAVARro Valls, Rafael,"Más allá del divorcio", en Alfa y Omega, № 423, de 4 de noviembre de 2003.
} 
cios producidos desde su implantación ${ }^{67}$. No obstante, no es menos relevante su trascendencia en el plano cualitativo por cuanto incide profundamente en la estabilidad del matrimonio y lo acerca al matrimonio romano, como situación de hecho sostenida por la affectio maritalis. En este mismo sentido se comprende que el automatismo del divorcio parece no justificar la existencia de un proceso, de ahí que se haya sugerido que para satisfacer la pretensión de obtenerlo podría ser suficiente el trámite de un expediente de jurisdicción voluntaria o, incluso, la comparecencia ante un fedatario público ${ }^{68}$.

Finalmente, hay que señalar otra disposición que también se proyecta sobre el matrimonio aunque, a la vista de las normas precedentes, reviste menor entidad. Se trata de la Ley $3 / 2007$, de 15 de marzo, reguladora de la rectificación registral de la mención relativa al sexo de las personas. Aquí también se invoca el libre desarrollo de la personalidad para atender la petición de los transexuales de

${ }^{67}$ Cuando se introdujo el divorcio en España, en 1981, uno de los argumentos que se emplearon para justificarlo fue decir que más de 500.000 matrimonios rotos esperaban su aprobación con impaciencia. Pese a ello, en el primer trimestre de aplicación de la Ley 30/1981 se produjeron 9.483 divorcios y en 1982 se registraron un total de 22.578 (cfr. ALBÁCAR, José Luis, "Informe sociológico sobre la aplicación de la Ley del Divorcio", en La Ley. Revista jurídica española de doctrina, jurisprudencia y bibliografía, 1983, 4, p. 1215). Sólo acumulando los divorcios durante casi veinte años, desde 1981 hasta el año 2000, se alcanza la cifra de 518.695 divorcios. Pues ahora, la Ley 15/2005 ha disparado el divorcio de tal manera que en sólo cinco años (2005/2009) ha alcanzado la cifra global de 533.972 divorcios. También se advierte que, a partir de 2005, el continuo crecimiento del número anual de divorcios experimenta un salto cualitativo, pasando de 50.974 divorcios en 2004 a 72.848 en 2005, para saltar a 126.952 en 2006 y, a partir de entonces, decrecer ligeramente: 125.777 divorcios en 2007, 110.036 en 2008 y 98.359 en 2009.En lo que se refiere a las separaciones, como era de esperar, éstas han ido disminuyendo: pasando de 81.618 en 2004, a 64.028 en 2005, para bajar drásticamente a 18.793 en 2006 y seguir haciéndolo en los años sucesivos, pasando a 11.583 separaciones en 2007, 8.761 en 2008 y 7.680 en 2009. Cfr. Instituto Nacional de Estadística, Estadística de nulidades, separaciones y divorcios, en http://www.ine.es/jaxi/menu.do?type=pcaxis\&path=/t18/p420/p01/\&file=inebase[visitado el 07/07/11].

${ }^{68}$ Cfr. TAPIA Fernández, Isabel, "El nuevo proceso de divorcio tras la promulgación de la Ley 15/2005, de 8 de julio: ¿necesidad de un proceso especial?, ¿necesidad de un proceso?", en Aranzadi Civil, 1, 2006, p. 2262. Vid. también NAVARRO VIÑUALES, José María, La tendencia desjudicializadora en el nuevo Derecho de Familia, enIdem (dir.), El nuevo Derecho de Familia: Modificaciones legislativas y tendencias doctrinales, Civitas, Cizur Menor, 2006, pp. 286-290. Estas consideraciones me llevan a recordar la propuesta que formuló Clavería Gosalbez hace unos años de concebir el matrimonio como "la unión del hombre y la mujer que han exteriorizado, de determinada forma prevista en la ley, su propósito de convivencia estable: existiría, por tanto, matrimonio por y tras la comunicación formal al Registro civil de dicho proyecto de convivencia. En este contexto, la figura del divorcio carece de sentido, bastando, en línea de principio, la mera comunicación (a modo de "denuncia") al mencionado Registro, por parte de uno de los cónyuges, para que legalmente se repute extinguida la relación matrimonial. El matrimonio se aleja así de la idea de "vínculo" para presentársenos como hecho afectivo juridificado: no nos hallaríamos ante un acto jurídico instantáneo que genera un vínculo duradero sino ante (...) [un] "acto jurídico permanente", es decir, un acto que continuamente está celebrándose, debiendo la conducta de sus autores ser reputada, no acto de cumplimiento, sino de creación o constitución de una relación jurídica" (Clavería GosálbeZ, Luis-Humberto,"Hacia una nueva concepción del matrimonio", en La Ley. Revista jurídica española de doctrina, jurisprudencia y bibliografía, 1983, p. 1298). 
modificar la inicial asignación registral del sexo y del nombre propio, adecuándolos a su nueva identidad de género ${ }^{69}$. Llama la atención que la norma no sólo prioriza el sexo psicológico o psicosocial sobre el sexo gonadal y sobre el sexo cromosómico, sino que para proceder a la rectificación registral de la mención del sexo no exige que la reasignación incluya necesariamente cirugía ${ }^{70}$, por lo que el transexual podría conservar los caracteres sexuales primarios (genitales) de su sexo morfológico ${ }^{71}$.

\section{REFLEXIONES FINALES}

Al término de esta exposición y, en particular, a la vista de las reformas que ha experimentado el matrimonio en la legislación española durante los últimos años, y que coinciden sustancialmente con las que se han llevado a cabo en otros países de Occidente, podemos preguntarnos: ¿qué es el matrimonio civil?, ¿qué queda de su modelo inicial, inspirado en el modelo canónico?

Concluiremos sin dificultad que se ha producido un fenómeno de vaciamiento gradual de la institución en sus aspectos sustanciales, de tal manera que al final resulta irreconocible. El matrimonio ya no se caracteriza por la indisolublidad, suprimida primero por el divorcio remedio y luego por el divorcio exprés, que va más allá y también cuestiona su estabilidad. La ordenación a la generación de los hijos deja de ser un fin objetivo en la medida que desaparece el impedimento de impotencia y se produce una disociación de la relación sexo-matrimonioprocreación, con la medicalización de la sexualidad (sexo sin niño) y lo que se ha podido llamar un cierto encarnizamiento procreativo (niño sin sexo) ${ }^{72}$. La heterosexualidad ha dejado de ser un elemento constitutivo del matrimonio, al reconocerse a los homosexuales el derecho a contraer matrimonio entre sí, al tiempo que se subjetiviza la sexualidad con el transexualismo y transgenerismo.

\footnotetext{
${ }^{69}$ Cfr. "Exposición de motivos de la ley", en Boletín Oficial del Estado, de 16 de marzo de 2007, pp. 11251-11252.

${ }^{70}$ En efecto, para proceder a la rectificación registral la ley exige que el solicitante acredite "que le ha sido diagnosticada disforia de género" (art. 4.1.a) y "que ha sido tratada médicamente durante dos años para acomodar sus características físicas a las correspondientes al sexo reclamado" (art. 4.1.b); pero añade que "no será necesario (...) que el tratamiento médico haya incluido cirugía de reasignación sexual (...)" (art. 4.2).

${ }^{71}$ Evidentemente, esto va mucho más allá de la transexualidad y se sitúa en el ámbito del transgenerismo de la Teoría Queer, que reivindica una sexualidad en continuo cambio y movimiento, a voluntad del sujeto, y que se traduce en identidades sexuales múltiples (cfr. Elósegu Itxaso, María, "Modelos de familia y heterosexualidad del matrimonio. El Estado y el derecho ante la realidad familiar", en IzQuierdo, César y Soler, Carlos (eds.), Cristianos y democracia, Eunsa, Pamplona, 2005, pp. 299-306). Para un análisis de los aspectos jurídico-médicos de la orientación sexual y de su relación con el matrimonio, cfr. ídem, La transexualidad. Jurisprudencia y argumentación jurídica, Comares, Granada, 1999, pp. 7-125.

${ }^{72}$ Cfr. R. Navarro-Valls, Matrimonio y Derecho, cit., pp. 115-116.
} 
Esta pérdida de identidad del matrimonio contribuye a su desjuridificación, de la que es exponencial la conversión del consentimiento matrimonial en un a priori, y el paradójico proceso de juridificación de las uniones de hecho y su tendencial equiparación al matrimonio.

El matrimonio en la legislación civil pasa a convertirse en un término vacío de contenido o tan comprehensivo que resulta inútil. Por eso, a la pregunta de ¿qué es el matrimonio?, podemos responder diciendo que no es más que "la unión voluntaria de dos personas independientes"73.

Frente a esta imagen del matrimonio civil, desinstitucionalizada y privada de sus caracteres básicos originarios, se alza el matrimonio canónico como modelo clásico de matrimonio que cuenta con una historia bimilenaria y con la fuerza que le da ser una realidad vigente en un ordenamiento de carácter universal y que rige una comunidad de más de mil ciento ochenta millones de personas $^{74}$, de todos los países y de todas las culturas. La regulación canónica del matrimonio mantiene, sin solución de continuidad, su trayectoria de respeto y protección de las propiedades y elementos esenciales de la institución, en coherencia con la dignidad de la persona humana y su naturaleza. De este modo, el matrimonio canónico sigue ofreciéndose a la mirada del legislador estatal como el modelo clásico del matrimonio en el que nuevamente podrá encontrar fuente de inspiración y pautas a seguir cuando inicie el camino de retorno a la institución matrimonial.

\footnotetext{
${ }^{73}$ Según la expresión empleada en 1969 por Herman Kling, Ministro de Justicia de Suecia (1959-1969), citada por SUNDBERG, Jacob W. F., "Marriageor no marriage: The Directives for the Revision of Swedish Family Law",en The International and Comparative Law Quaterly, 20, 2, 1971, p. 233.

${ }^{74}$ Cfr. las cifras en Vatican Information Service, de 21 de febrero de 2011.
} 
